\title{
The Development of a Research and Extension Program for Sustainable Agric ulture in Western Washington
}

Carol A. Miles

AdDITIONAL INDEX WORDS. sustainable, organic, alternative production, on-farm research

SUMmaRY. Sales of organic foods are one of the fastest growing segments of Washington state's food industry. In response to grower demand for information on organic and sustainable production practices, Washington State U niversity (WSU) created an Extension Agricultural Systems position. This position has been instrumental in helping WSU gain the trust and recognition of organic growers. The position enabled WSU to demonstrate that it has a commitment to organic and sustainable research and extension activities. This paper describes the key activities of this position: 1) finding out research needs, 2) on-farm research approaches, 3) formation of regional research programs, and 4) creation of the WSU Food and Farm C onnections Team. G rant funded on-farm research, interdisciplinary teams, and extension publications have been major emphases of the position.

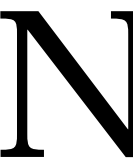

ational sales of organic foods are increasing $20 \%$ to $30 \%$ annually, making organic food the fastest growing segment of the food industry (M iles et al., 2000b). In 1998, Washington state's food industry sold over $\$ 70$ million in organic food. With this increase in production, there is increasing demand from organic growers for universities to provide research-based information suitable for organic production systems. O rganizations such as Washington Tilth Association (association of organic growers, Seattle, Wash.) and the Washington Sustainable Food and Farm N etwork (Bellingham, Wash.) have been gaining a greater political voice in Washington and are making their needs known to legislators and the leadership at Washington State $U$ niversity (WSU ). In response, WSU has increased research and extension programming targeted towards organic and sustainable producers. 


\section{Extension agric ultural systems program}

In 1994, WSU created an Extension Agricultural Systems position in response to requests from growers in southwest Washington. Position responsibilities included working with organic and conventional commercial agricultural producers, conducting on-farm research, investigating alternative pest control strategies, and developing viable alternative crops. These responsibilities were carried out by 1 ) assessing research and extension prioritiesin theregion through asurvey of small farms; 2) conducting on-farm trials with alternative crops and pest control strategies; 3 ) targeting extension education towardsorganic and sustainable growers by forming interdisciplinary regional research and extension programs; and 4) participating in the WSU Food and Farm Connections Team (FFCT). This paper will discuss these four program areas.

IDENTIFYING RESEARCH AND EXTENSION PRIORITIES. In 1996, a small farm survey was distributed to 800 farmers in the Pacific northwestern U.S. (Washington, $O$ regon, and Idaho). M ailing lists for regional extension and small farm newslettersand state organic farmers were used for survey distribution. Of thesurveys distributed, 193 (24\%) were returned; 50\%ofrespondentswerefrom Washington and $25 \%$ were each from $O$ regon and I daho. O f therespondents, 138 (71\%) represented farms, 10 were farm businesses, 17 were agricultural agencies, and 28 specified themselvesas "other". Of the farmer respondents, $71 \%$ were organic.

Survey participants were asked to identify pest management and soil fertility research and extension priorities. Respondents identified biological controls, beneficial insects, crop management, cultivation, companion planting, and cover crops as the most important pest management research and extension priorities (Table 1). Cover crops, compost, rotation, intercropping, manure, and microbial conditioners were the most important soil fertility priorities (Table 2).

In 1997, participants at the session entitled I dentifying R esearch Priorities at the Washington State Tilth Conference identified potato flea beetles (Epitrix cucumerisH arris), potato scab (Streptomycesscabi esT haxt.), potato late blight (Phytophthora infestans M ont.), cabbage root maggot (D elia radicum L.), symphylids (Scutiger ella

Table 1. The three most important pest management practices identified for research, and the number of respondents (NR) for each.

\begin{tabular}{lclcc}
\hline 1st choice & NR & 2nd choice & NR & 3rd choice \\
\hline Crop management & 32 & Beneficial insects & 27 & Biological controls \\
Biological controls & 29 & Biological controls & 20 & 30 \\
Beneficial insects & 18 & Crop management & 19 & Beneficial insects \\
Cultivation & 17 & Cover crops & 18 & Cultivation \\
Companion planting & 14 & Companion planting & 16 & Companion planting \\
Cover crops & 12 & Traps/ pheromones & 13 & Cover crops \\
Botanical pesticides & 12 & Cultivation & 15 & Botanical pesticides \\
Traps/ pheromones & 9 & H erbicides & 14 \\
Herbicides & 8 & Botanical pesticides & 10 & management \\
Chemical pesticides & 7 & Chemical pesticides & 8 & Traps/ pheromones \\
Flaming & 4 & Row covers & 7 & Trap crops \\
Trap crops & 3 & Trap crops & 8 & Chemical pesticides \\
Row covers & 2 & Flaming & 7 \\
Fallow systems & 1 & Fallow systems & 4 & H erbicides \\
Other & 14 & Other & 2 & Flaming \\
No response & 11 & No response & 4 & Fallow systems \\
\end{tabular}

T able 2. The three most important soil fertility practices identified for research, and the number of respondents (N R) for each.

\begin{tabular}{lclcl}
\hline 1st choice & N R & 2nd choice & NR & 3rd choice \\
\hline Cover crops & 38 & Rotation & 26 & Cover crops \\
Compost & 37 & Cover crops & 25 & Compost \\
Rotation & 20 & Compost & 25 & Intercropping \\
Chemical fertilizers & 17 & M anure & 19 & M icrobial conditioners \\
Intercropping & 13 & Intercropping & 17 & Rotation \\
M icrobial conditioners & 13 & Kelp/ seaweed & 13 & M anure \\
M anure & 12 & M icrobial conditioners & 8 & Plant/ Animal by-products \\
Plant/ Animal by-products & 6 & Chemical fertilizers & 7 & Kelp/ seaweed \\
Biosolids & 3 & Rock powder & 5 & Biosolids \\
Rock powder & 3 & Plant/ animal by-products & 5 & Lime \\
Kelp/ seaweed & 3 & Biosolids & 4 & Rock powder \\
Lime & 0 & Lime & 4 & Chemical fertilizers \\
Other & 11 & Other & 3 & O ther \\
No response & 17 & N o response & 32 & N o response \\
\end{tabular}


immaculata Newp.), gray mold (Botrytis cinerea Per. ex Fr.), carrot rust fly (Psila rosaeF abr.), and western spotted cucumber beetle (Diabrotica undecimpunctata $M$ ann.) as the most important pests to study. Pollinators, multicropping, compost production, disease suppressive soils, beneficial organisms, and avian habitat were also identified as important study issues. Findings from the small farm survey and the tilth conference session were used to establish research and extension priorities for organic and sustainable agriculture in Washington.

On-farm research. An on-farm research program wasinitiated in 1996 to begin study of alternative pest control strategies, alternative crops, and manuremanagement. A successful onfarm research program is a well-coordinated team effort among growers, industry representatives, and researchers. G rowers and industry representatives identify key research issues and collaborate with researchers to design, conduct, and evaluate experiments. A multidisciplinary research team is the ideal working group for on-farm trials as in many cases the research issues involvecomplex systemsthat areinterrelated and interdependent. Grant funding is critical to the success of onfarm research trials as extra field labor is needed to plant, maintain, and harvest plots. $D$ ata collection must bewell coordinated with farm timelines in order to preserve the marketability of crops. Treatments must be appropriate to ensure that organic certification of a host farm is not jeopardized. The following studies outline some of the research activities conducted on alternative pest, crop, and soil fertility management.

Alternative pest control. In 1995, an organic grower identified carrot rust fly as the most significant pest affecting her carrot (D aucus carota $L$. Ann) crop. With the assistance of a Grower/ Rancher Sustainable Agriculture Research and Education (SARE) research grant, a medic (Medicago litoralis L.) intercrop was assessed as a potential control option (Rämert, 1993). When carrot rust fly damage was measured at harvest, marketable yield in the medic intercrop plots was about 20\% greater than in plots that had no intercrop (M iles et al., 1996). The grower, however, decided not to utilizean intercrop becauseit interfered with mechanical weed management.
In 1996, an on-farm study was initiated to investigate pea root damage on a large, conventional farm growing green peas (Pisum sativum L.) for processing. Corn root worm, the larval stage of western spotted cucumber beetle, was identified as the primary cause of root damage in pea ( $M$ iles and Amrhein, 1999). This was the first time corn root worm was documented damaging green peas (M ileset al., 1998). In collaboration with peafarmers and processing industry representatives, chemical and biological control options for corn root worm were investigated in processing green peas. The study included three species of entomopathogenic nematodes in addition to several chemical treatments. In this study, the biological control options were as effective as the best chemical control options(M ileset al., 2000a). As a result of this work, an extension publication on the use of entomopathogenic nematodes as biological control organismsisbeing developed.

Raspberries ( $R$ ubusi daeusL .) area high-value crop in western Washington, and root rot (Phytophthora fragaria var. rubi $\mathrm{H}$ ickman) is a severe disease common to both organic and conventional farms. At thistime, organic growers have no control options for raspberry root rot, and the current chemical controls for conventional growers are not adequate(Bristow, 1999). In 1999, an organic farmer expressed an interest in testing Trichoderma harzianum $R$ ifai and several other productsfor control of raspberry root rot (H arman, 1996; C. $\mathrm{K}$. H ayes, personal communication). $O$ ther treatments included in the study weregypsum (M .P. Pritts, personal communication; Bristow, 1999) and composted manures (H oitink et al., 1991). The grower regularly applies composted manure to raspberries as an in-row nutrient mulch and was interested in exploring this amendment as a disease control strategy. This study was the first organic research funded by the newly expanded mandate of the Washington State Commission on Pesticide Registration. The new mandate allows commission funds to be used to investigate organic controls and integrated pest management strategies(Schreiber, 1998). O btaining this funding and carrying out this and similar studies have donemuch to boost the confidenceand support of the organic community towards WSU 's research and extension programs.

Alternative Crops. Rapid urbanization of western Washington has resulted in high land values as well as complaints by new neighbors against many common farming practices (e.g., dust, odors, perceived health risksfrom pesticide applications, etc.). The low market values of conventional bulkcommodity crops along with an increase in the number of small-acreage farms has resulted in increased grower demand for high-value crops. Alterna-

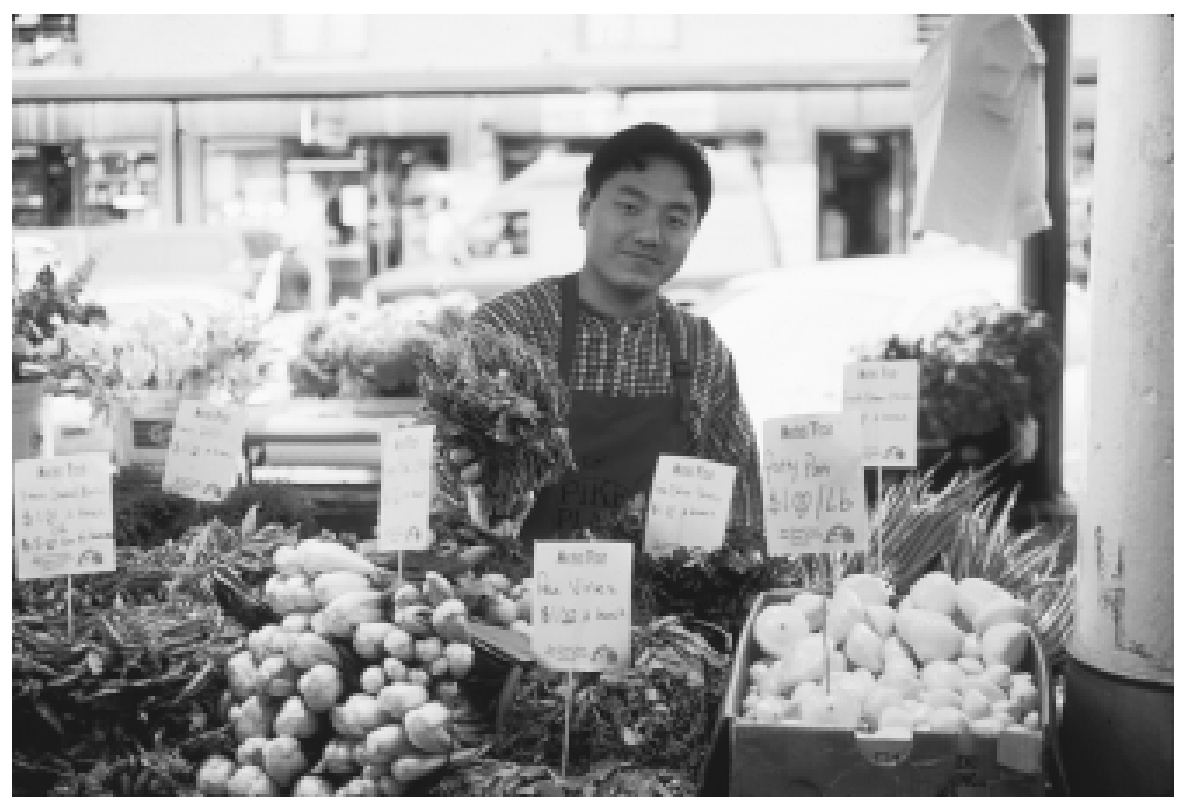

Fig. 1. H mong farmer selling pea vines, an alternative vegetable crop, at the Pike Place M arket, Seattle, W ash. 
tive high-value crops investigated in western Washington includeedamame (Glycinemax L.), baby corn (Zea mays L.), pea shoots, wasabi (Wasabi japonica Miq.), and bamboo (Bambusoideae). O n-farm variety trials have been conducted to monitor performance, yield, agronomic and pest issues, and marketing potential sof these crops (Fig. 1). Extension publications have been developed to provide growers with production information. A collaborative effort is underway with a local commercial laboratory to initiate wasabi tissue culture because affordable, disease-free plant material limits wasabi production in theU nited States. A bamboo variety trial is being conducted in collaboration with theA merican Bamboo Society (Albany, N.Y.) and the Thurston Conservation D istrict (O lympia, Wash.). The conservation district is interested in the high nitrogen uptake potential of bamboo. If it shows promise, they are potentially interested in promoting bamboo as a manure management tool.

Manure management. Most organic growers in western Washington utilize dairy and poultry manure as a nutrient source for vegetable and fruit production. H owever, many growers are not familiar with the nutrient values of the manure, how to calculate application rates, or how and when to best apply manure. In 1997 and 1998, WSU Cooperative Extension and the Thurston Conservation District conducted an on-farm manure utilization study and published a manureresource guide. The on-farm study included four types of manure (fresh dairyscreenings, composted dairy screenings, fresh poultry fryer, and fresh poultry layer) applied at agronomic rates to an organic pumpkin (Cucurbita pepo L. 'N ew England Pie') field. It was demonstrated that pumpkin yields were equivalent in all plots which received manure as compared to plots which received commercial organic fertilizer. The $M$ anure R esource Guide( $M$ iles et al., 1999) provides growers with manure nutrient analysis information, examples of how to calculate agronomic rates, guidelinesfor appropriate manure application, information regarding water quality and food safety issues, and contact information for manure producersin the region. Additionally, on-farm workshops and field eventswereheld for growers, students, and the general public.

\section{Washington State University Food and Farm Connections Team}

Formed in 1997, the FFCT is a self-directed regional team of about 25 extension and research faculty that has been supported by the WSU C enter for Sustaining Agriculture and $\mathrm{N}$ atural Resources. The team was formed to increaseinterdisciplinary collaboration, to extend faculty's individual expertise throughout the region, and to respond to demandsfrom clientelefor information and programming on sustainable food systems. By forming a team, faculty have been able to share resources and expertise where funding, staff reductions, or heavy workloads limit programming opportunities. The mission of theFFCT is to promote sustainable, communitybased agricultural systems and provide research and extension programs for growers, consumers, decisionmakers, and others involved in local food systems. Five FFCT members volunteer as executive committee members and meet monthly to discuss program updates, budgets, tasks, and issues. Core team programs include conferences and workshops, a new series of extension publicationsentitled FarmingW est of the Cascades, a World Wide Web (web) site, and the U rban Community-Based Food Systems Degree/ Certificate.

Conferences and workshops. In 1997, the WSU Small Farm Conferencedrew about 500 participants, making this the largest gathering of organic, alternative, and small producers in the state. Conference organizers and many of the presenterswereFFCT members. TheFFCT is partnered with community groups and agencies to plan and coordinate the 2000 conference, Farm to Table: Growing H ealthy Foodshedsand Communities. Thisconference drew about 350 participants, including state and county political leaders, restauranteurs, public health workers, producebuyers, farmers, university faculty and staff, and general consumers.

Farming west of the Cascades. This new series of WSU extension publicationsis being authored by team members. These publications are targeted towards small growers in western Washington and address organic and alternative production issues. Farm management publications in the series includemanure applications, soil management, and record keeping. Crop production publications include edamame, baby corn, pea shoots, wasabi, pastures, and haymaking. 0 ther publications include organic certification, building trust with consumers, value-added on the farm, and nematodes as biological control organisms.

Website. In 1998, the FFC T eam created a Web site (Kropf et al., 1998) as a virtual center for organic and sustainable crop production in Washington. Though this site is still in the development stages, the FFCT strives to provide online information regarding crop and livestock production, publications, a calendar of events, and links to other institutions around the country with the focus on sustainable agriculture issues.

Community-BAsed URBan FOOd SYSTEMS. In 1999, a collaborative effort between WSU and TheE vergreen State College resulted in a joint course, Community-Based U rban Food Systems. The Evergreen State College is a 4-year institution in western Washington with afocuson sustainable agriculture. The course was advertised jointly and course outlineswere posted on the Web (M ichael-Butler et al., 1999). Faculty from the FFCT lectured and led field trips that focused on small, organic, and sustainable farms in urbanized communities.

\section{Organic agriculture issues}

Similar to other areas of the $U$ nited States, in Washington state there has been a lack of understanding and trust between organic growers and the land grant university. Growers have complained that extension agents and researchers did not provide information relevant to organic growers. For their part, many organic growers lack an understanding about research, that funding is needed to conduct trials, and that it requires years of testing to draw scientifically valid conclusions. Also, within theorganic community in Washington state, there has been little or no consensus regarding where and how to start an organic research program.

At the university level, professors, researchers, and extension agents at land grant universities have been perceived as insensitive and unhelpful regarding the needs of organic growers. $\mathrm{H}$ istorically, there has been very limited support for organic and sustain- 
able education and research at many universities. Core undergraduate curricula generally have not provided significant information about organic and sustainableagricultureor have not provided this information in a positive light. Although elective classes on organic and sustainable agriculture may exist, many students are not encouraged to take theseclasses. M ost faculty at land grant institutions do not have significant amounts of training in organic or sustainable agriculture and are not encouraged to seek training in these areas. Additionally, when many new faculty are hired, often little emphasis is placed on awareness, experience, and implementation of organic and sustainable agriculture. It is encouraging to see state and federal initiatives supporting these issues, but significant funding for organic and sustainable agriculture are urgently needed and will benefit all food production systems.

At the regulatory level, many organic pesticides lack sufficient efficacy data, thus preventing their registration with the state department of agriculture pesticide division. A valuable service that university researchers could provide to organic growers is the inclusion of organic products in standard pesticide trials and the provision of efficacy data to support registration where appropriate. Another issue is that some product formulations prevent the product from being certified organic. An example is biological control substrates, which include greater than the allowable level of synthetic urea. Regulatory agencies could provide companies with formulation limitationsand regulationsfor organic certification.

\section{Maximizing university efforts}

O rganic farmers need sound research-based information on which to base production decisions. R esearchers need to test and study organic pest control and soil fertility options along with conventional options. Research stations need to consider devoting a section of land as organic or sustainableto enablefaculty to conduct meaningful studies. U niversity leadership needs to acknowledge and support faculty who are striving to create organic and sustainable programs. In this time of budget constraints and demands for new information, faculty must develop partnerships with other institutions, agencies, organizations, communities, and farmers, and obtain funding for organic and sustainable programs, trials, and publications. Perhaps the biggest challenge of all is that all this must be done while continuing to provide ongoing support to conventional growers. Faculty have a unique opportunity and challenge to develop and promote new information which will have positive impacts on organic as well as conventional agricultural systems. This process will bring together two groups of agricultural professionals who are often seen as dissimilar, though both desire to produce high quality food products while maintaining good stewardship of their land.

\section{Conclusions}

TheAgricultural Systems Program and the FFCT have helped WSU gain the recognition and support of many organic growers throughout the state. Today, WSU is recognized as striving to support organic and sustainable research and extension activities. The needs of organic farmers in Washington state are being incorpo rated into a university-based research program and partnerships are being formed among university faculty and organic and sustainable agriculture organizations. These partnerships are perceived as essential for the continuation and further development of university programs for organic and sustainable agriculture. Finally, funding strategies must be developed to enable all university faculty to participate and provide science-based leadership in organic and sustainable agricultural issues.

\section{Literature cited}

Bristow, P. 1999. Controlling Phytophthora root rot of red raspberry: An integrated approach. Wash. State U niv. Coop. Ext. Pacific N orthwest Sust. Agr. N wsit. 10(4):4-5.

H arman, G. 1996. Trichoderma for biocontrol of plant pathogens: From basic research to commercialized products. Cornell Comm. Conf. Biol. Control, 11-
13 Apr. 1996. 20 Apr. 2000. http:/ / www.nysaes.cornell.edu/ ent/ bcconf/ talks/ harman.html.

H oitink, H .A.J ., Y. I nbar, and M .J . Boehm. 1991. Compost can suppress soilborne diseases in container media. Amer. N urseryman. 15 Sept.:91-94.

Kropf, J, S. M aier, and C. M iles. 1998. Wash. State U niv. Coop. Ext. Food and Farm Connection. 20 Apr. 2000. http:/ / foodfarm.wsu.edu.

M ichael-Butler, L., M . H enderson, and L. Gray. 1999. N ew community based urban foods systems course. Wash. State U niv. Coop. Ext. Food and Farm Connection. 20 Apr. 2000. http:/ / foodfarm. wsu.edu/ foodcourse.

M iles, C., L. Zenz, B. DeWreede, and J. Puhich. 1996. O n-farm research: Intercropping in carrots for rust fly control. Grower/ rancher Sustainable Agr. Res. Educ. grant final report. 20 Apr. 2000. http:/ / agsyst.wsu.edu/ carrot.htm.

Miles, C, T. Wright, and M. Amhrein. 1998. Corn root worm video clips. Wash. State U niv. Coop. Ext. 20 Apr. 2000. http:/ / agsyst.wsu.edu/ crw.

M iles, C. and M. Amrhein. 1999. Corn root worm in green peas. Agronomy $A b$ stracts, p. 111.

M iles, C, T. Cheeke, T. Flores, W. $M$ atthews, and J. Clougherty. 1999. From end to beginning: a manure resourceguide for farmers and gardenersin western Washington. Wash. StateU niv. Coop. Ext. L ewis County Publ. 20 Apr. 2000. http:/ / agsyst.wsu.edu/ manure.htm.

M iles, C., C. Chen, C. Blethen, R. Carr, and M. Amhrein. 2000a. Control of corn root worm in green peas. Proc. W. Wash. H ort. Assn. Conv., SeaT ac, Wash., p. 3537.

Miles, C., T. Flores, and M. M cEvoy. 2000b. O rganic food production and certification in Washington state. Wash. State U niv. Ext. Bul. EB 1888.

Rämert, B. 1993. M ulching with grass and bark and intercropping with Medicago litoralis against carrot fly (Psila rosae F.). Biol. Agr. H ort. 9(2):125-133.

Schreiber, Allen. 1998. Washington State Commission on Pesticide Registration response to the Food Q uality Protection Act. 20 Apr. 2000. http:/ / www.wscpr.org/ foodqual.html. 